\title{
REWRITING HART'S POSTSCRIPT: THOUGHTS ON THE DEVELOPMENT OF LEGAL POSITIVISM
}

\author{
Tom CAMPBELL*
}

Resumen:

Este artículo propone una lectura de la primera edición de El concepto de derecho (1961), de H. L. A. Hart, en la cual se recuperan los elementos de prescripción moral que acompañan a la tesis descriptiva/explicativa que Hart explícitamente defendió. De tal modo, la tesis funcionalista del surgimiento de normas secundarias en sociedades complejas depende de la importancia de los beneficios sociales, relacionados con la justicia y la eficiencia, los cuales Hart suscribe. Después se llama la atención sobre la forma en que el Post Scriptum a la segunda edición de El concepto de derecho (1994), publicado póstumamente, podría ser reescrito para tomar en cuenta respuestas a Dworkin distintas a las que ofreció el propio Hart en su Post Scriptum. La alternativa de una forma tentativa de un positivismo jurídico prescriptivo "duro" conservaría de mucho mejor manera los ingredientes prescriptivos que son tan evidentes en la 1a edición, y contribuiría a la regeneración de una filosofia del derecho analítica contemporánea dentro de la tradición hartiana.

Palabras clave:

Positivismo jurídico, jurisprudencia analítica, moral, positivismo ético, H. L. A. Hart.

* Centre for Applied Philosophy and Public Ethics, Charles Sturt University, Australia. 


\title{
TOM CAMPBELL
}

\begin{abstract}
:
The article suggests a reading of the 1st edition of $H$. L. A. Hart, The Concept of Law (1961) which involves bringing to the fore the elements of moral prescription which accompany the descriptive/explanatory intent which Hart himself explicitly espouses. Thus, the functionalist account of the emergence of secondary rules in complex societies draws on the importance of social benefits, relating to justice and efficiency, benefits which Hart endorses. Consideration is then given to how the posthumous Postscript in the $2^{\text {nd }}$ edition of The Concept of Law (1994) might be rewritten to take into account responses to Dworkin other than those adopted by Hart in the Postscript. The alternative of a tentative form of prescriptive 'hard' legal positivism would better preserve the prescriptive ingredients evident in the $1^{\text {st }}$ edition and assist in the regeneration of contemporary analytic legal philosophy within the Hartian tradition.
\end{abstract}

\section{Keywords:}

Legal Positivism, Analytical Jurisprudence, Morality, Ethical Positivism, H. L. A. Hart. 
Summary: I. Introduction. II. Re-reading "The Concept of Law". III. Rewriting the Postscript. IV. Conclusion.

\section{INTRODUCTION}

Legal Positivism comes in many forms: conceptual, descriptive, explanatory and normative (that is, morally evaluative or prescriptive). Legal Positivism is now generally thought of as being an descriptive/explanatory theory but there is a prescriptive or ethical form of legal positivism according to which one element of a desirable system of law is that it consists of relatively precise rules that can be identified and understood without recourse the moral or other controversial opinions of those whose duty it is to follow or apply the law. In slightly more technical terms, this may be called 'prescriptive exclusive positivism' according to which a legal system ought to combine a rule of recognition, that can be applied without having to make disputable moral judgments, with a set of rules that apply directly to the conduct of legal subjects that are expressed in similarly amoral terms. ${ }^{1}$

H. L. A. Hart, on the other hand, at least in The Concept of Law, ${ }^{2}$ is avowedly conceptual and explanatory in a sociological vein, albeit with a hermeneutical bent that seeks to explain social institutions, such as law, through identifying the meaningfulness of social relationships for those involved, often using the conceptual methods of ordinary language philosophy according to which attention to linguistic usages as they arise in working contexts is seen as a fruitful way of uncovering explanatory social meanings and dis-

1 Campbell, Tom, Prescriptive Legal Positivism: Law, Rights and Democracy, London, Cavendish Publishing, 2004.

2 Hart, H. L. A., The Concept of Law, Oxford, Clarendon Press, 1961, second edition 1994. Page references in this article relate to the 2 nd. edition. 
solving unproductive conceptual puzzles. ${ }^{3}$ Thus Hart believes that the nature of social and legal obligation can be illuminated by attending to the difference between our use of "obliged" and "obligation", which points us in the direction of explaining the authority of law through the interaction of different types of social rules, such rules being explained in part as generally observed patterns of conduct accompanied by what may be called a supportive internal attitude on the part of members of the society or group in question. This is the renown "model of rules" that is intended to express the conceptual cum sociological essence of all developed legal systems as involving the union of primary rules, which apply directly to conduct of law subjects and secondary rules, which identify, change and direct the enforcement of first order rules. ${ }^{4}$

This model is presented as descriptive and explanatory rather than evaluative or prescriptive. But there is, methodologically, more to Hart that this, and I am not here referring just to his general corpus much of which is clearly morally evaluative, but to The Concept of Law itself. There is much in the actual argumentation and presentation of that book which can be read as involving the moral views of the author. ${ }^{5}$ Indeed it is not difficult to discern elements of strong normativity in Hart's method, elements that contribute to the attraction and persuasiveness of his theory of law. These normative elements are largely covert and never pervasive, but may be perceived, nevertheless, as being operative at crucial stages of his analysis of the concept of law.

3 Hart, H. L. A., Essays in Jurisprudence and Philosophy, Oxford, Clarendon, 1983, p. 346.

4 In fact the label comes from Dworkin, Ronald M., "The Model of Rules", University of Chicago Law Review, vol. 35, 1967, pp. 14-46. Hart himself does not confine his theory of legal norms to rules alone.

5 See McCormick, Neil, H. L. A. Hart, London, Edward Arnold, 1981, p. 25: 'Indeed, as Hart frankly acknowledges at the end of his book [The Concept of Law, chapter 9, pp. 206-7] the ultimate basis for adhering to the positivist thesis of the conceptual differentiation of law and morals is itself a moral reason'. 
Such a reading of The Concept of Law comes up against the difficulty that it is not Hart's intention or self-perception to be the constructing a morally prescriptive theory of law. Famously, he sets out in the book to engage in what he calls "descriptive sociology", albeit through conceptual analysis of legal discourse. 6 And in the 1994 Postscript, included in the posthumous $2^{\text {nd }}$ edition of that book, it is emphatically re-affirmed that it is the aim of The Concept of Law to provide "a theory of what law is that is both general and descriptive".7 "My account" he writes "is descriptive in that it is morally neutral and has no justificatory aims: it does not seek to justify or commend on moral or other grounds the forms and structures which appear in my general account of law, though", he adds, "a clear understanding of these is, I think, an important preliminary to any useful moral criticism of law". ${ }^{8}$ Ignoring the caveat for the moment, such explicit statements of denial should surely put an end to any speculation about the proper interpretation of that work.

However, authors are not the sole authority on the meaning of their utterances, especially when these are released to the public forum in published form. Certainly we owe it to authors to make a sincere effort to understand what they are seeking to say, but in examining what they have published we are entitled to read it in the light of its public meaning and the way in which the work is likely to be understood by its readers. Bearing this in mind, it is useful and illuminating to explore the contention that there is much in what Hart wrote in The Concept of Law that transcends his denial of prescriptive intent. Indeed, I suggest

6 The Concept of Law, vi: 'Notwithstanding its concern with analysis the book may also be regarded as an essay in descriptive sociology; for the suggestion that inquiries into the meaning of words merely throw light on words is false. Many important distinctions, which are not immediately obvious, between types of social situation or relationships may best be brought to light by an examination of the standard uses of relevant expressions and of the way in which these depend on social context, itself often left unstated'.

7 Ibidem, p. 239.

8 Ibidem, p. 240. 
that this reading of Hart, explains some of the appeal of Hart's theory that arises from a reasonable understanding of that work as a significantly prescriptive social and legal theory to the effect that, defeasibly, an organised system of clear mandatory rules is generally socially and morally beneficial and ought to be encouraged. Of course, the normativity in question assumes the feasibility of the model and rests on an understanding of how legal systems are and may possibly become, but this does not mean that the factual content of a theory is not sometimes to be seen as part of an evaluatively directed theory.

This prescriptive reading of The Concept of Law would be in line with the tenor of most of Hart's other work. Indeed, Hart constantly adopts prescriptive lines of argument in most of his writings. He is firmly committed to arguing in favour of controversial positions in legal and political philosophy, such as the need to retain mens rea as a basis for excuses in the criminal law, ${ }^{9}$ and the rejection of paternalistic morality as a basis for the content of criminal law. ${ }^{10}$ As a reasonably faithful successor to the Benthamite positivism which upholds the distinction between law as it is and law as it ought to be, Hart's prescriptive activities as an applied ethical philosopher are perfectly legitimate for a positivist as long as they are keep clearly and distinctly separate from evaluatively neutral conceptual and descriptive analysis. Hart does not have to repudiate the evaluative nature of much of his other work in order to claim that The Concept of Law is a morally neutral exercise in sociologically oriented conceptual analysis. However, no such bright line between the prescriptive and the descriptive contributions in Hart's work overall. Throughout his many scholarly undertakings there is certainly a constant endeavour to achieve conceptual clarification (and much of this is directly related to the search for a general descriptive theory of law) but his conceptual analysis is frequently closely to

9 Punishment and Responsibility, Oxford, Clarendon Press, 1968.

10 Law, Liberty and Morality, London, Oxford University Press, 1963. 
repeated efforts to undermine poor evaluative arguments for unpalatable evaluative conclusions and a willingness to take the initiative in providing a framework for progressive liberal thought.

Even if the main thrust of The Concept of Law is providing an understanding of law that is relatively neutral as between different types of legal system, good and bad, it would be surprising, given Hart's admiration for Bentham, if this were not closely allied to an assumed normative outlook poised to take the field in its own right. Like Bentham's, Hart's approach is broadly utilitarian, and is crucially shaped by a belief in the social utility of rules as well as their potential as instruments in the causation of grave harm. This intermingling of prescription and description is not in itself a problem. The two logically distinct modes must be systematically related in applied philosophy, although, as Hart insisted, there must always be vigilance if we are to avoid illicit moves from "is" to "ought" - the much discussed "naturalistic fallacy"- or, as I surmise is more prevalent in Hart's work, illicit moves from "ought" to "is" - the less noticed "normative fallacy" in which beliefs about what ought to be the case improperly impact on assertions about what is the case. ${ }^{11}$

In the first edition of The Concept of Law itself, Hart is quite relaxed about introducing normative considerations to explain and defend his theory. It is only in the 'Postscript', included in the $2^{\text {nd }}$ edition published posthumously in 1994, that he is definitive in rejecting an evaluative interpretation of the book. Perhaps, he was pressured into this position by Dworkin's critical commentary and adopted a more extreme view than the more eclectic approach of the first edition. For whatever reason, in the Postscript, which is based on his unpublished notes, Hart openly rejects any reading his account of the union of primary and secondary rules as being in any way a recommendation of legality or

11 Campbell, T. D., "The Normative Fallacy", The Philosophical Quarterly, vol. 20, 1970, pp. 368-77. 
the outline of a morally desirable system of law rather than a morally neutral account of systems of law in general. Moreover, there he endorses unequivocally soft (or "inclusive") positivism, that is the thesis that rules of recognition can and often do contain moral criteria for the identification of valid law, and he makes this acknowledgement without expressing any regret that this is the case, or even any concern that it might undermine his explanatory theory.

Most commentaries on the Postscript gloss over Hart's option of adopting a more prescriptive stance related to the good consequences that flow, for both social cooperation and justice, from the instantiation of the governance of rules. Thus in the collection of essays edited by Jules Coleman, ${ }^{12}$ with the notable exception of Jeremy Waldron, little attention is paid to this possibility. Waldron alone considers seriously whether Hart may be read as a "normative (or ethical) positivist". ${ }^{13}$ As he explains these terms in another essay, Waldron notes "We need to distinguish, however, between: first, the value judgments that might be required in a nonpositivist jurisprudence to identify some propositions as a valid legal norm; and second, the value judgments that support the positivist position that evaluations of the former type should not be necessary'.14 Perhaps, if Hart been clearer in his own mind about this distinction, and less concerned to protect his original methodological classification of The Concept of Law, he would have seen that the arguments he put forward are often in substance evaluative arguments for having, in a complex society, a rule of recognition that can be applied

12 Jules Coleman, ed., Hart's Postscript: Essays on the Postscript to The Concept of Law (Oxford, Oxford University Press 2001).

13 Although Stephen Perry comes close in discussing Hart as a 'methodological positivist' (Coleman, op. cit, pp. 311-354) and Liam Murphy discusses the normative reading of Hart, and concedes that Hart does draw on moral grounds to justify some aspects of his concept of law (Coleman, op. cit., pp. 371-409).

14 Waldron, Jeremy, "Kant's Legal Positivism", Harvard Law Review, vol. 109, 1996, pp. $1535-66$ at 1541 . 
without recourse to evaluative judgments and first order rules that are similarly operatively morally neutral.

To argue that Hart is a covert prescriptive legal positivist is not simply to re-read the Postscript, it is to re-write it. Why should we do this? One excusing reason is that Hart did not himself publish the notes that have been put together in the Postscript despite many opportunities to do so. Perhaps he had doubts about the content of the material he had prepared and left unfinished and unpublished at his death. However, there is no indication that he would have given any credence to such a rewrite, although he may have been tempted to make some retractions. He may have thought that to do so would be to concede too much to his critics and undermine the distinctiveness and integrity of his theory which had by that time reached canonical status. ${ }^{15}$

There is therefore some basis for re-reading The Concept of Law from a normative perspective. In doing so, it may bring forward a more convincing basis for many of the book's central theses, which sometimes lack the empirical bases to lay claim to be an example of descriptive sociology, and, at the same time, it come to serve more as a source of inspiration for prescriptive legal philosophies of a positivist hue which can present a more critical approach to current legal practice that other contemporary versions of analytical legal philosophy.

\section{RE-REAding "THE CONCEPT OF LAW"}

Re-reading The Concept of Law from a morally prescriptive point of view, deploying a certain amount of the hindsight of the later developments in legal theory is an interesting exercise.

The strongest and most evident grounds on which it can be argued that The Concept of Law is open to an evaluative

15 Lacey, Nicola, A Life of H. L. A. Hart: the Nightmare and the Noble Dream, Oxford, Oxford University Press, 2004, chapter 14, especially pp. 348-55. 
reading lies in his straightforward account of the transition from a simple society, that is a society with nothing but first order rules by way of normative ordering, to a complex society with a combination of primary and secondary rules, with the secondary rules (that is rules about rules) having to do with the ways in which primary rules are to be officially identified, interpreted, changed and enforced. In chapters 5 and 6 of The Concept of Law, the main thrust of his explanation for the emergence of the ingredients of a developed legal system derives from the social benefits that follow from the emergence of a legal system in an increasingly complex and changing society. We are taken through the image of a simple society with customary rules only, rules that are stable through time, widely held and respected, and enforced in a unorganised way through informal sanctions, to the official organisation of a system of rules through the activities of specialist officials who make, mould and apply the rules they officially identify and apply on behalf of the rest of the relevant social group. And we are given the clear indication that theses changes actually do provide the certainty, efficiency and flexibility required in more complex social environments.

To develop this interpretation, and taking a cue from Hart's commitment to the ordinary language philosophy of the time, we may attend to the language he uses in presenting this aetiological tale, which might otherwise be regarded as no more than a value free functionalist explanation. The story unfolds through the progressive identification of 'defects' in a system of customary rules that turn out, in an increasingly complex and changing society, to be too static, too ill-defined, too informal and too disorganised to meet the needs of more developed social groups. Basically, the thesis is that the defects of having only primary rules are overcome through the introduction of the secondary rules, the rules of the officials whose job it is to identify, change and apply primary rules, and in particular through the rule of recognition that sets out the criteria 
that must be satisfied for a primary rule to be considered as part of law rather than simply an informal custom. The defect of everyone enforcing the rules for themselves which is highly chaotic, and therefore both inefficient and unfair, is dealt with by setting up a central authority whose task it is to decide when the rules have been broken and what should be done about it. The defect of static rules is overcome by providing some mechanisms for change so that the society as an organised whole can respond effectively to novel circumstances. So the model of rules is clearly better than that which preceded it on a number of counts, at least for the type of societies in which the defects of the simpler system are manifest. Hart then goes on to talk of the "The pathologies' associated with those legal systems that have not quite made it as legal means of social control, with further talk of 'failures' and 'breakdowns' of such legal systems. ${ }^{16}$

Further on, where he writes of "the protections and benefits provided by the system of mutual forbearances which underlies both law and morals", ${ }^{17}$ Hart notes that "the step from the simple form of society, where primary rules of obligation are the only means of social control, into the legal world with its centrally organized legislature, courts and officials and sanctions brings its solid gains at a certain cost. The gains are those of adaptability to change, certainty, and efficiency, and these are immense; the cost is the risk that the centrally organized power may well be used for the oppression of numbers with whose support it can dispense, in a way that the simpler regime of primary rules could

16 The Concept of Law, p.118. Stephen Perry notes that 'while it is possible to discern elements of the descriptive-explanatory method in Hart's approach to doing legal theory, there are good reasons for believing that he does not in fact employ that method, or at least that he does not employ it in anything like a pure form. The most important reasons is that Hart adopts the characterization of law that he does, expressed in terms of the union of two types of rule, on the basis of evaluative judgments that have nothing to do with the metatheoretical criteria for assessing theories...' "Hart's Methodological Positivism" in Coleman, Jules, ed., Hart's Postscript, Oxford: Oxford University Press, 2001, p. 315.

17 Ibidem, p. 200. 
not". ${ }^{18}$ While such evaluations are not unequivocal, they are unequivocally evaluations.

All this can be read as an explanation of the emergence of legal systems on the model he describes. The assumption might be that these are intentionally introduced changes that are designed to and actually do make social outcomes better than they were before. We can thus understand why they were introduced and are maintained. This can be read as an explanation not an evaluation. And where such accounts of social change are couched in more functionalist terms without reference to the conscious intentions of the participants they can be rendered explanatory by the assumption of some sort of social natural selection with changing social equilibria and ongoing historical selection.

Yet, such explanations, whether or not they draw on conscious intentionality, can also be read as prima facie justifications of such change. Of course people may be wrong about the benefits to be derived from the changes, and we may challenge their belief that the alleged benefits are indeed benefits, or that they justify the alleged costs. There is no deductive move here from is to ought, no naturalistic fallacy. But apparently functionalist explanations are capable of being read and assessed as value judgments which, if sound, would justify maintaining and where appropriate changing the systems that have emerged as a result of their perceived or actual advantages. When this is done, there may well be a tendency to read back from the justifications to an idealised picture of the reality - the normative fallacy at work - thereby diverting attention from the need for empirical evidence to support even the hermeneutical form of social explanations.

The symbiosis here between the realm of meaning explanations and that of normative justification is clear. Thus in his account of the existence and functioning of social rules, Hart emphasises the internal point of view whereby those involved in the societies in question have certain beliefs and

18 Ibidem, p. 202. 
attitudes towards their rules and adherence to them, including certain beliefs about the social utility and importance of such rules. Such beliefs not only explain why the rules persist but provided a starting point for a discussion of whether they ought to exist. We can accept that the beliefs and their justification are distinct without undermining the relevance of their justificatory use in deciding whether legal systems are a good idea and in deciding what sort of legal systems ought to be preferred.

As Hart himself makes clear in the Postscript it is, of course, possible to describe and explain the moral judgments of others without endorsing them. ${ }^{19}$

However, the historical story is reinforced by Hart in terms of what he sees as the uncontroversial values which he endorses as a form of minimal natural law. Here Hart draws on "the moral convictions which most of us share" 20 including the protection of life, bodily security and property rights that are required to sustain living conditions without which a tolerable life, even life itself, could scarcely continue. The primary rules themselves that are to be found in every society are taken to be uncontroversially justifiable if not in every detail at least in their general thrust. At this level sociological imperatives are not in tension with moral ones. This broad awareness of the general aims and advan-

19 Ibidem, p. 243 (in the Postscript): 'Even if...the participant's internal perspective manifested in the acceptance of law as providing guides to conduct and standards of criticism necessarily also included in a belief that there are moral reasons for conforming to law's requirements and moral justification of its use of coercion, this would also be something for a morally neutral descriptive jurisprudence to record but not to endorse or share.'

20 Hart, H. L. A., Punishment and Responsibility, Oxford, Oxford University Press, p. 88. His methodology is set out on page 10. In relation to any social institution 1) state the general aim or value it fosters and 2) enquire after principles limiting the pursuit of that aim or value. Thus the purpose of criminal law is to prohibit certain types of conduct...the primary task of securing society from evil...but there are limitations as to how this objective may be prosecuted. In the same book, he notes, on p. 22, the importance in criminal law of "fair opportunity" and "the power to identify beforehand the particular periods when he will be free of them [sanctions]". 
tages of social institutions is a recurring theme of Hart's work.

The endorsement of a minimal morality is clearly distinct from what Hart calls 'critical morality' which functions to comment and commend with respect to existing social norms, but there is no indication that the sort of critical morality that Hart endorses involves the repudiation of the basic values identified in his explanatory/normative model. So what we have are the ingredients of a justification for developing and assessing legal systems, including the values that are relevant to assessing the advantages and disadvantages of having such systems at all. It is important to note here that the scarcely concealed generally positive evaluation of secondary rules is parasitic on the social value of having primary rules. The attractions of law are built on the attractions of rule-governance in general. Thus, Hart's picture of the social utility of rules in protecting from harm and coordinating human conduct is not just a warm up for his legal theory but an integral part of that theory. The importance of the secondary rules is unintelligible without the prior analysis of the value of primary rules. Primary rules are therefore as essential to Hart's cryptoevaluative account of law as are secondary ones. This is not, of course, a claim that rules are beneficial whatever their content, but that rules are an indispensable technique for securing certain types of social benefits. Only together do they provide the basis for a convincing theory of legal obligation.

Other evidence of Hart's evaluations and prescriptive goals emerge in his discussion of justice in The Concept of Law, particularly formal justice, where draws attention to the affinity of law and the justice involved in treating like cases alike. Here again Hart is careful with his words. He does not carelessly use "justice" for the sum of all or all important moral values, but relates it to the discourse of fairness and hence relates it to "maintaining or restoring a balance or proportion" in the distribution of benefits and 
burdens, for fairness he notes (with an eye to the context of ordinary language usage) is an idea closely associated with "shares". ${ }^{21}$ Moreover, it is clear that he takes it for granted that such a balance or proportion often requires the use of rules and their impartial administration, so that 'The connection between this aspect of justice and the very notion of proceeding by rule is obviously very close'. ${ }^{22}$ So, while he emphasises that, however fairly administered, a law may be unjust in its content, perhaps because it takes a morally irrelevant factor into account, he accepts the close association between having rules, which are administering impartially, and the very idea of justice.

It may be argued that by providing evaluative grounds for having rules Hart opens the way for critical morality to condemn some first order rules but that this critical morality does not affect his sociological explanation of legal systems or have implications for the choice of one style of legal system over another. This would mean that we could accept that Hart endorsed the role of value judgments in criticising particular legal rules but not in asserting the value of law as such. For he does not seem to tinker with the content of his model in order to commend a type of legal system that best fulfils its justificatory functions.

This certainly appears to be the position presented in the Postscript when it comes to the choice between "hard" and "soft" positivism, that is between excluding or including moral criteria in the rule of recognition. Given, as Dworkin had pointed out, there are legal systems that have moral principles in their rule of recognition and given that Hart is engaged in a descriptive exercise, it seem inevitable that Hart should agree that rules of recognition may contain moral criteria, hence his soft legal positivism. And this certainly fits with The Concept of Law in so far as he allows a role for morality in the exercise of judicial discretion in the interpretation of open-textured rules.

21 Ibidem, pp. 158-59.

22 Ibidem, p. 161. 
Yet, Hart is not required to stop there and in fact he does not do so. For instance, he effectively raises the question of what constitutes a good or effective rule of recognition. The answer is, in part, a rule that fulfils its role of settling disputes about the content of law. This comes up nicely in his analysis of legal realism and the role of discretion in regulation. He points out that talk of discretion arises in situations where there are rules to be applied but there is some leeway as to what they mean and how they should be applied. It is not simply that it makes no sense to speak of discretion when the scorer can decide what she likes, effectively making up the rules as she goes along (what Hart calls 'scorer's discretion'), but that such a system, taken to extremes, makes the game unplayable. In this discussion he happily speaks in terms of the advantages and disadvantages of having rules, of having a degree of discretion and of having authoritative determinations of what the rules are and whether they have been broken. ${ }^{23}$ This enables us to reject a rule of recognition that says what whatever the judge decides is the law is the law. This is the nub of Hart's critique of legal realism. He accepts that a rule of recognition that does not fulfil its function adequately is either a poor rule or not a rule at all. While within his descriptive approach he does not want to hold that all rules of recognition are effective beyond the point where a legal system may be said to exist, but he has to hand the values for making judgments about what is a good or bad rule of recognition and these are the values that are used in his account of why rules of recognition are adopted and sustained. 24

In this regard it is interesting to note that the rule of recognition is a social rule. although not in fact a legal one. It

23 Ibidem, p. 139.

24 Shapiro, Scott, J., 'On Hart's Way Out' in Coleman, op.cit., pp 149-92 at 177-78 'Inclusive rules of recognition do not tell judges which moral rules they should apply - they simply tell judges to apply moral rules. These rules cannot give epistemic guidance because judges are left to figure out for themselves what those rules are. Vis-à-vis such rules, they are like ordinary citizens'. 
follows that there is an internal attitude attaches to it. ${ }^{25}$ Assuming that we can accept that a rule of recognition established obligations for the officials, we can surmise that when those officials criticise departures from that rule they do so on the basis of their belief in the importance of the rule, and that this belief in the importance of having a rule is grounded in an awareness of the value of having some sort of rule of recognition, provided it fulfils its function. This gives further support to the idea that the theory assumes and contains the ingredients of a normative legal positivism that commends having a rule of recognition and by implication commends rules of recognition that satisfy certain functional criteria relating to the effective selection of rules for inclusion in the legal system.

Consider also Hart's assumption that each legal system has one rule of recognition. ${ }^{26}$ How does he come to that view? It is feasible, indeed empirically established, that judges in actual legal systems operate with a range of rules of recognition, some giving more significance to international law, others to strict statutory construction, others to the moral principles perceived to underlie the common law. Yet Hart claim that there is one rule of recognition that is the unifying feature, indeed the sovereign of each distinct legal system.

His Postscript response to this is that each legal system that there is general agreement on its rule of recognition. He thinks of this as a complex empirical fact. ${ }^{27}$ Yet he did not conduct such empirical research and his confidence in this matter may well be due more to his sense that the effective and just functioning of a legal system depends on there being consistency between judges with respect to

25 Ibidem, p. 146: 'To say that at a given time there is a rule requiring judges to accept as law Acts of Parliament or Acts of Congress entails, first, that there is a general compliance with this requirement and that deviation or repudiation on the part of individual judges is rare; secondly, that when or if it occurs it is or would be the subject of serious criticism and as wrong.'

26 Ibidem, pp. 100-12, 246.

27 Ibidem (in the Postscript), p. 292. 
rules of recognition. Judges and others have an obligation to strive for agreement on what that rule is to be. Only this can produce the coherence, clarity and decisiveness required by a legal system that is going to decide disputes, reduce harmful conduct and facilitate cooperative activities.

Further evidence of the underlying prescriptive nature of some of Hart's arguments derives from the Hart/Fuller debate as to the practical consequences of judges in an evil legal system adopting legal positivism as a practical philosophy. ${ }^{28}$ The well known disagreement is whether judges faced with grossly immoral laws should or should not regard them as laws at all. Fuller takes the view that if judges are sufficiently attached to a form of natural law that enables them to see that such laws are not properly regarded as laws and should not therefore be enforced they are less likely to adjudicate in blind obedience to evil rulers. Hart, to the contrary, argues that positivist judges, attuned to the distinction between law as it is and laws as it ought to be, are more ready to accept that current laws are immoral and therefore to take a moral stand against them.

Whoever wins this particular debate - and it would appear to be matters of fact that mainly divide the protagonists - what is going on is a prescriptive argument for or against the legal theories involved based on their alleged consequences. Here we appear to have Hart engaged in prescriptive positivism, commending his legal theory on moral grounds. ${ }^{29}$ This may be too strong. After all, Hart would insist that he is only saying that legal positivism does not have the unfortunate consequences it is alleged to have, in that it does not have the result of increasing adherence to evil laws. These considerations may not, however, affect his

28 Hart, H. L. A., "Positivism and the Separation of Law and Morals", Harvard Law Review, Vol. 71, 1958, p.593-629; Fuller, Lon, "Positivism and Fidelity to Law: A Reply to Professor Hart', Harvard Law Review, Vol. 71, 195, p. 630.

29 As Fuller suggests, ibidem, at p. 673: 'Professor Hart's essay seems to me to open the way for such a discussion for it eliminates from the positivist philosophy a pretense that has hitherto obscured every issue touched by it. I mean, of course, then pretense of the ethical neutrality of positivism.' 
decision to adopt the theory. Nevertheless, it is difficult to believe that they do add some weight to his position, and go some way towards explaining Hart's tenacity in defending the positivist thesis. ${ }^{30}$

The protagonists in this debate do not call in the empirical evidence that might resolve most of their differences. Instead, they seem to rely more on the logical implications of the theories in question. Fuller sees legal positivism as implying that judges must apply rules which they do not approve of, and Hart says that natural law requires us to accept that existing law is morally justified. Fuller's case does not seem intuitively compelling unless we assume that rules of recognition do not include moral criteria, that is, unless we assume hard legal positivism, and Hart's criticism must be directed inter alia against having moral criteria in the rule of recognition, for that is what encourages us to believe that positive laws have passed moral tests. What is involved here is effectively a debate about what ought to be the form and content of the rule of recognition, that is between hard and soft legal positivism. Hart is defending both the distinction between law as it is and law as it ought to be and a legal theory that requires judges and others to adopt a rule of recognition that is exclusive of moral considerations, and acquiesces in Fuller's assumption that this is precisely what legal positivism entails. It is not simply the holding of abstract views on the distinction between ought and is that gives rise to different judges reactions to evil regimes, but views about what sort of rules of recognition judges ought to follow. This is, therefore, far more than a marginal dispute about the moral side effects of legal posi-

30 Murphy, Liam, "The Political Question of the Concept of Law", in Jules Coleman (ed.), Hart's Postscript, Oxford, Oxford University Press, 2001, pp. 371-409 accepts this 'quietism' argument in relation to the population in general, but only to a limited extent, and denies that it makes Hart's general theory prescriptive. See also Liam Murphy, "Concepts of Law", Australian Journal of Legal Philosophy, Vol. 30, 2005, pp. 1-19, Dyzenhaus, David, Hard Cases in Wicked Legal Systems, Oxford, Clarendon, 1991. 
tivism. Rather, it is an issue at the core of the debate about what constitutes a desirable system of law.

Hart's objection to Fuller's is not about his general theory of the internal morality of law in so far as it points to the benefits of systems of rules that are clear, prospective, general, practicable and stable. His argument is, that such legal systems are not necessarily just or beneficial. Fuller, Hart thinks, overstates the moral significance of formal fairness, the beneficially efficacious outcome of formally good laws, and the role of purpose in adjudication. In his words: "The difference between the author [Fuller] and those he criticises on this matter is the activity of controlling man by rules and the principles designed to maximize its efficiency are not valued by the latter or their own sake and are not dignified by the title of 'a morality'. They are valued so far as they contribute to human happiness and other substantive moral aims of the law'. ${ }^{31}$

It is not only the phenomenon of evil legal regimes that flushes out the prescriptive thrust of some of Hart's analyses. Another debate, between Hart and Patrick Devlin, also brings to the surface moral arguments for the adoption of legal theories with specific implications for what constitutes a good legal system. ${ }^{32}$ In that debate Devlin had argued for the enforcement of morality in the criminal law because a society has to have one cohesive and consistent pattern of right and wrong in relation to such matters as sexual conduct and the associated institutions of marriage and divorce. Hart wishes to defend a liberal line on issues such as the criminalisation of homosexual conduct along the lines of J. S. Mill's harm principle according to which conduct may not be criminalised if it does not cause harm to others. Victimless crimes should not be crimes, therefore, even the general opinion that something is immoral is not in itself a

31 Hart, H. L. A., Essays in Jurisprudence and Philosophy, Oxford, Clarendon Press, 1983, p.357.

32 Hart, H. L. A., Law, Liberty and Morality, London, Oxford University Press, 1963. 
reason for prohibiting it in law. To establish this position it is important for him to show that there is logical space between morality and law. Hart' position here may be compared to Neil MacCormick's 'moral disestablishmentarianism', the principle that nothing should be made law simply because it is morally approved or disapproved, even (or perhaps especially) by the (moral) majority, a position MacCormick presents as 'a moral case for amoral law'.33

This may look like a straightforward disagreement about the desirable content of first order rules. However, as many positivists have pointed out, the de facto distancing of morals and laws cannot be done without the capacity to distinguish the domain of law from the domain of morality. If moral criteria are introduced to the rule of recognition then this capacity to restrict law to the prevention of harm and the promotion of prosperity, for instance, will be in vain to the extent that such moral criteria play a role in the identification of law. And so, at the very least we can see that there is a congruity between normative legal positivism and Hart's strong liberal position that he adopted in the Hart/Devlin debate, which allowed him to argue that moral approval of heterosexuality is not in itself a reason for criminalising homosexuality. To operationalise such a system it is necessary to omit from the rule of recognising the criminal law any criterion along the lines of protecting 'morals'. ${ }^{34}$

33 Neil MacCormick, 'A Moralistic Case for Amoralistic Law', 20 Valparaiso University Law Review, 1985, 1-42.

34 It may be argued that Hart himself introduces a moral criterion into the rule of recognition in the form of the Millean 'harm principle' to the effect that the criminal law may be used to prohibit and deter individuals harming other people. But there is no evidence that Hart saw the harm principle as a desirable candidate for a rule of recognition. Remember, the principle says that the law may be used to prevent harm in these sense that it may not be used to prevent anything that is not harmful to others. It does not say that causing harm to others is a sufficient basis for rendering a type of conduct unlawful. In fact it is clear that Hart assumed that the question of whether or not harmful behaviour warrants criminal obligations is a matter for debate and decision within the political and ultimately the legislative process. 
This accumulation of evidence demonstrates that it is not only possible but natural and illuminating to read The Concept of Law as in part an exercise in normative legal philosophy which points to the social value of primary rules and thence of legal systems constituted through a shared rule of recognition, and does so in a way which endorses the potential utility of law, and provides reasons that can feature in the determination of what makes for a good legal system, in terms of its formal features as well as its substantive content.

\section{Rewriting The POSTSCRIPT}

The Postscript cannot readily be interpreted even as covert prescriptive legal positivism. There Hart explicitly and sometimes stridently affirms his descriptive/explanatory intent, moves away from an emphasis on the significance of law as a system of primary rules (as distinct from principles) and appears to repudiate all prescriptive exercises beyond defending the importance of taking a critical attitude to law.

Here we cannot re-read, but we can re-write. In terms of the development of legal positivism, the moves Hart made in response to Dworkin's critique of the model of rules may be unfortunate in so far as they dismiss the prescriptive and evaluative elements at work kin the legal positivist tradition. From this point of view it would have been better if he had affirmed the centrality of primary rules within a legal system for reasons of formal justice and administrative efficiency. He could have noted that admitting moral criteria into the rule of recognition weakens its social utility for the resolution of disputes, the coordination of conduct and the democratic authority of legislation. He could have identified those points at which his theory is not only normative but in conflict with Dworkin's ideal of a legal system dominated by Herculean judges exercising their moral judgments as to what best justifies existing bodies of law and 
developing that law in accordance with those principles. And he could have done all this while still maintaining that there are large elements of purely descriptive analysis in his work and denying that, in making law the best that it can be', the substantive moral view of judges must be decisive in legal process.

The Dworkinian criticisms that Hart is answering in the Postscript are (a) that law contains principles as well as rules (b) that the rule of recognition falls foul of the 'semantic sting' whereby it reduces legal disagreement to disagreement about the definition of law, which it clearly is not, and (c) that legal positivism has to be seen as an interpretive theory dealing with such issues as the justification of state coercion. In the Postscript, Hart's response to these criticisms is a mixture of capitulation and defiance. Capitulation with respect to the centrality of rules and defiance with respect to claim that his descriptive theory does not come into conflict with Dworkin's overtly prescriptive approach.

The first and central concession was to declare his theory compatible with Dworkin's model of rules plus principles. Hart firmly endorses soft or inclusive legal positivism by accepting that there are rules of recognition that contain principles, and that principle are norms that give moral reasons of various weight for determining the law to be this or that. This is, perhaps, an inevitable move if Hart is to maintain his purely descriptive/explanatory commitment. He can hardly deny the many ways in which it is accepted in many systems that morality should enter law through the opinions of judges. That seems incontrovertible empirical fact. Nor can he deny the logical space created for this possibility by the concept of the rule of recognition, for once that rule is in operation it can be used to identify as law whatever satisfies its criteria, and this certainly need not involve simply choosing between putative legal rules.

Yet, Hart could have insisted that effective legal systems are in large measure rule-based, both with respect to the criteria in the rule of recognition and the fact that their pri- 
mary norms are social rules, with principles coming in largely in complex interpretive issues and permitted judicially initiated rule-change. Frederick Schauer provides a possible model here with his analysis of rule-based decision making and its social benefits as something that is by and large descriptively accurate as well as normatively desirable. ${ }^{35}$ Better still, Hart could have explained the potential benefits of such systems and argued for developing systems of law that enables us to identify the official rules of our mandatory system of norms in ways that do not involve moral judgments. That is, he could have given us grounds for adopting hard or 'exclusive' legal positivism in a system of rules as an ideal with which to go into battle against Dworkin's scheme of moral reasoning in law.

These moves would have provided Hart with a much more convincing explanation of legal obligation. His attempt to distance legal obligation from mere coercion is weak on a purely descriptive approach. Its attraction lies in adding the social utility of social obligations to be added to the obligation that comes from the social utility of having a system that serves the function of identifying and applying a specially important set of those rules. Legal obligation thus draws on the moral force of primary as well as secondary rules, for we have need of both. When all the weight of legal obligation goes on to the secondary rules, with no requirement that these are choosing between primary rules for which there are social justifications, then the analysis of legal obligation loses the force of the combination value of primary and secondary rules. Hart would correctly insist that such primary rules may in fact be evil and the value of having secondary rules may be entirely negated by that fact. Nevertheless the fact that rules of recognition are limited to the role of choosing between primary rules that have potential utility by virtue simply of their being rules rather than because of their particular content, gives a depth to

35 Schauer, Frederick, Playing by the Rules: A Philosophical Examination of Rule-Based Decision-Making, Oxford, Clarendon, 1991. 
the (limited) content that a positivist would want to give to the notion of legal obligation. Law of a positivist kind gives rise to stronger prima facie reasons for obeying that law than would be the case were the rule of recognition be not constrained by the need to select rules or by the use of moral criteria in the rule of recognition. The positivist point still remains that these derive from the moral reasons for having a system of authoritative rules to govern social life, moral reasons that may always be outweighed by the content of the first order norms and the ineffectiveness of the second order norms.

As it is, Hart is left with less support for his earlier claim that legal positivism provides a basis for developing a critical moral approach to law by institutionalising the separation of law and morality. Only a hard or exclusive positivism can fit his story of the benefits of law as a union of primary and secondary rules, his emphasis on the affinity of formal justice and law, his desire to prevent people imposing their morality on the private conduct of others and the implication that we should be encouraged to adopt a morally critical view of the content actual laws.

Adopting a laissez faire attitude to admitting moral criteria in rules of recognition greatly reduces the practical significance in his distinction between is and ought in law, as can bde seen beyond Jules Coleman's unadventurous concept of negative positivism: the thesis that there is at least one possible legal system in which the rule of recognition contains no moral criteria, as a denial that there is a necessary relationship between law and morality. ${ }^{36}$ What Hart does descriptively is to emphasise the de facto overlap of law and morals in language, function and content. What he could have done normatively is to encourage a conceptual distance between law and morals in which his liberal utilitarian aims can flourish.

36 Jules Coleman, "Negative and Positive Positivism", Journal of Legal Studies, Vol. 11, 1982, pp. 139-64. 
At another conceptual extreme, Hart could have argued for hard or exclusive positivism as a conceptual thesis, an objective to which Joseph Raz aspires, on the grounds that only a system that enables us to identify laws without recourse to moral judgment can play a role in guiding conduct in situations where there is moral dispute. ${ }^{37}$ This reads remarkably like a normative argument for the utility of hard positivism, and indeed this is in places how Raz appears to present his sources thesis, that is the thesis that law must be identified through some sort of social fact, such as an enactment. ${ }^{38}$ It is highly unlikely that Hart would have contemplated such an approach as he eschews propagating conceptual necessities and would surely want to say that actual legal systems are better and worse at guiding conduct, yet it would certainly be closer to the gist of his own theory than an open ended descriptive pluralism that has no strong objection to admitting moral criteria into the rule of recognition and the content of first order rules.

Why Hart did not make some such moves is more a question for biographers than philosophers. ${ }^{39}$ It is clear from the content and rhetoric of some of the controversies in which he was involved that he could take to defending his position with as much zeal as any academic out to sustain his own theory. It may be that he was so impressed by the significance of ordinary language philosophy and its repudiation of first order moral theory as a respectable academic exercise that his methodological loyalties held him back. It may be that he thought that once he had admitted a measure of prescription into his theory he would have to abandon the important and largely feasible objective of providing a general descriptive account of legal systems and accept

37 Raz, Joseph, "Authority, Law and Morality", Monist, Vol. 68, 1985, p.195: "its [law's] existence and content can be identified by reference to social facts alone, without resort to any evaluation".

38 Raz, Joseph, Between Authority and Interpretation, Oxford, Oxford University Press, 2009, Part II.

39 See Lacey, op. cit., chapter 13. 
Dworkin's invitation to see his theory as essentially 'interpretive' (ie prescriptive). ${ }^{40}$

Hart was surely wrong in holding that there is "no significant conflict between enterprises so different as my own and Dworkin's conceptions of legal theory'. ${ }^{41} \mathrm{He}$ may not have been as narrow as Dworkin in confining his attention to the need for a theory of law to justify coercive state activity and its moral limits. But his theory does focus on mandatory social rules and he does produce arguments whose logic is to point up the desirability of government coercion being exercised through the medium of rules. Less controversially, it is clear that by allowing that his theory is open to a more Dworkinian form of legal reasoning he deprives himself of the argument that the second order rules he introduces to solve the defects of a simple normative system will improve the conditions of uncertainty from which they are meant to rescue simple societies as they become more complex.

Interestingly, while the Postscript concedes little to Dworkin, Hart does let his descriptive guard down when he is drawn into an evaluative disagreement that brings to the surface aspects of his underlying motivation. In countering Dworkin's disingenuous suggestion that he (Hart) take his own theory to be interpretive, that is ultimately an evaluation of what law ought to be, Hart insists that certainty is by no means the only legal value of importance to him. He accepts that meeting expectations is "a particular moral merit which law has, not the whole purpose of law", 42 and comments that limited discretion is not unjust because in interstitial areas there are no expectations to disappoint. ${ }^{43}$ $\mathrm{He}$ also notes the importance of identifying in advance use of coercive measures and private powers. ${ }^{44}$ But he takes the

40 Dworkin, Ronald M., Laws's Empire, London, Fontana, 1986, p. 52.

41 The Concept of Law, p. 241.

42 Ibidem, p. 249.

43 Ibidem, p. 276.

44 Ibidem, p. 250. 
certainty to derive from what he calls 'plain fact positivism' as only part of a system of good legal reasoning: "Exclusion of all uncertainty is not a goal which I considered'45 for "there are other aims which law should cherish". 46 This refers back to his earlier preference for a limited measure of judicial discretion in the interpretation and application of rules where this is required by the open texture of language. In that discussion he clearly sees the value of such open texture in permitting incremental legal development in the light of judicial first hand knowledge of actual social circumstances. Thus, orderly and sensible change is valued by Hart as well as certainty, clarity and decisiveness.

These comments reveal Hart as something less than a covert hard legal positivist. Perhaps one might call him a firm, rather than soft, positivist, or, in Schauerian terms, even a presumptive prescriptive positivist. ${ }^{47}$ Certainly his apparent willingness to adopt soft positivism may be seen as in part a recognition of the value of a certain amount of mushy law, as advantageous in enabling incremental legal change, providing opportunity for judicial leadership, and for increasing consistency in the total body of law administered by courts. So, it seems clear that as a prescriptive legal theorist Hart is not a thorough-going hard legal positivist, but it does show that he is deeply concerned with prescriptive legal theory, with what sort of legal system and what concept of law is best in our circumstances, how much judicial discretion is a good thing, how specific we want our rules to be, what sort of secondary rules we want to adopt for purposes of adjudication, and so on. This enables him to deny that he is a single minded hard or inclusive legal positivist but it does not answer the suggestion that his theory is, in substantive methodological terms, is in part, morally prescriptive.

45 Ibidem, p. 252.

46 Ibidem, p. 273.

47 Frederick Schauer, Playing by the Rules: A Philosophical Examination of Rule-based Decision-Making, Oxford, Clarendon, 1991. 
That leaves us with Dworkin's 'semantic sting', the reductio ad absurdum of theories that seek to define law by a set of empirical criteria. This can be dealt with briefly, for it is clearly mistaken to apply this critique to Hart because he was so very much against providing tight definitions to encompass complex social phenomena. Here his fascination with Wittgenstein's conception of "family resemblances" and subtle differences in linguistic usage come into play. Hart seeks to bring out the similarities and differences between, for instance, law and morality in a fluid way. He is not interested in a definition of the term 'law' in terms of the necessary and sufficient conditions of its use.

What then of the rule of recognition? Well, it is clear that, for Hart, on any reasonable interpretation, rules of recognition are not definitions of law. They relate to a variety of tests with different criteria in different jurisdictions for the purpose of providing official determination as to which rules are to be accepted as being laws in that jurisdiction. By assuming that this is fulfilling the same function as a sociologist's or a philosopher's definition of law Dworkin makes, although he denies he is making, the mistake of confusing the method of identifying a social phenomena and the description of the content of that phenomena. Of course Hart does use rules of recognition to determine whether or not a mature legal system exists, but Dworkin confuses the conceptual/sociological question of what constitutes a legal system from the quite different questions as to what criteria judges do or should use in identifying primary laws.

\section{CONCLUSiON}

Why should anyone seek to rewrite the Postscript to the $2^{\text {nd }}$ edition of one of the most famous legal philosophy books of the late modern period, especially if this involves going counter to the author's clearly stated contentions concerning his own work? Passing by the point that the 
publication of the Postscript was not authorised by Hart himself, the main justification for such a presumptuous exercise is that it may help to display the continuity of one reading of The Concept of Law, in the form of its immensely influential $1^{\text {st }}$ edition, with current theories of law that are, in part, morally prescriptive inclusively of the most general concepts within philosophical jurisprudence, such as legality, the rule of law and law itself. This may help to reconnect legal positivism with its Hartian precursors, such as Hobbes and Bentham, and open up the possibility of drawing on the insights of Hart himself to develop a contemporary prescriptive version of legal positivism. 